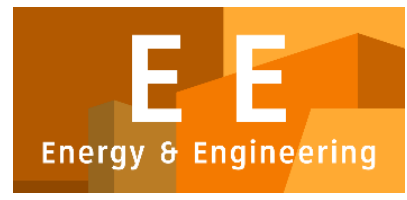

PAPER - OPEN ACCESS

\title{
Konsentrasi Co2 Pada Ruang Kelas Dengan Sistem Ventilasi Alami, Tipe Jendela Gantung Atas
}

\author{
Author \\ : Basaria Talarosha \\ DOI \\ ISSN \\ : 10.32734/ee.v1i1.123 \\ E-ISSN \\ : 2654-7031 \\ : 2654-704X \\ Volume 1 Issue 1 - 2018 TALENTA Conference Series: Energy and Engineering
}

\section{(a) $(\mathbb{\theta})$}

This work is licensed under a Creative Commons Attribution-NoDerivatives 4.0 International License.

Published under licence by TALENTA Publisher, Universitas Sumatera Utara
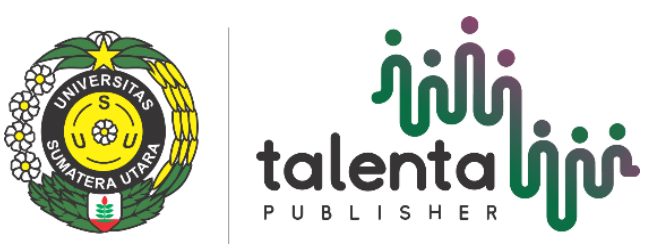


\title{
Konsentrasi $\mathrm{Co}_{2}$ Pada Ruang Kelas Dengan Sistem Ventilasi Alami, Tipe Jendela Gantung Atas
}

\author{
Basaria Talarosha ${ }^{\mathrm{a} *}$, Valencia Rosardy \\ ${ }^{a}$ Fakultas Teknik, Universitas Sumatera Utara, Medan 20155, Indonesia \\ basaria@usu.ac.id
}

\begin{abstract}
Abstrak
Proses pernafasan menghasilkan udara yang mengandung 4,4\% volume CO2 sehingga konsentrasi $\mathrm{CO} 2$ di dalam ruang kelas dapat menjadi lebih tinggi dari ruang luar jika ventilasi tidak mencukupi. Konsentrasi CO2 > 1000 ppm akan mengganggu kesehatan dan konsentrasi belajar yang berdampak pada penurunan performa belajar siswa. Penelitian sebelumnya menunjukkan adanya hubungan antara konsentrasi $\mathrm{CO} 2$ di dalam ruang kelas dengan ukuran, jumlah, posisi dan tipe jendela pada ruang kelas yang menggunakan sistem ventilasi alami. Tipe jendela gantung atas disebutkan memiliki performa yang paling buruk dalam menetralkan konsentrasi $\mathrm{CO} 2$ di dalam ruang. Studi bermaksud mengukur kadar konsentrasi $\mathrm{CO} 2$ di dalam sebuah ruang kelas pada salah satu sekolah dasar negeri di kota Medan yang menggunakan tipe jendela gantung atas. Pengukuran konsentrasi CO2 dilakukan pada kondisi sudut bukaan jendela sisi koridor ruang kelas $10 \square$ dan $30 \square$ masing-masing selama tiga (3) hari. Hasil studi menunjukkan konsentrasi CO2 maksimum pada kondisi sudut bukaan jendela 10 $\square$ lebih rendah dari pada kondisi sudut bukaan jendela 30LI, namun konsentrasi $\mathrm{CO} 2$ rata-rata pada kedua posisi jendela masih di bawah ambang batas konsentrasi $\mathrm{CO} 2$ yang diijinkan untuk kesehatan $(<1000 \mathrm{ppm})$.
\end{abstract}

Kata Kunci: konsentrasi $\mathrm{CO} 2$; jendela gantung atas; ruang kelas;

\section{Pendahuluan}

Kualitas udara di dalam ruang kelas dipengaruhi oleh kondisi ventilasi [21] dan akumulasi pencemar udara yang bersumber dari dalam maupun dari luar ruang. Pencemar udara di dalam ruang kelas bersumber dari penghuni dengan segala aktiftasnya [1], material bangunan [7] dan perabot di dalamnya. Pencemar udara yang terdapat di dalam ruang kelas antara lain karbon dioksida atau $\mathrm{CO}_{2}$ [23], volatile organic compounds atau VOCs [19], partikel berbahaya PM2.5 dan PM10 [22], nitrogen dioksida atau $\mathrm{NO}_{2}$ [2], formaldehyde, serta jamur dan mikroorganisma [5].

Konsentrasi $\mathrm{CO}_{2}$ di dalam ruang dengan densitas tinggi sebagaimana ruang kelas seringkali lebih tinggi dari konsentrasi $\mathrm{CO}_{2}$ udara luar jika ventilasi tidak mencukupi. Penyebabnya adalah proses pernafasan manusia yang menghasilkan 4,4\% volume $\mathrm{CO}_{2}$ setiap kali bernafas. Konsentrasi $\mathrm{CO}_{2}>1000$ ppm akan mengganggu kesehatan [16], konsentrasi belajar (Twardella et al., 2012), dan performa belajar siswa [9], khususnya pada anak usia sekolah 
dasar sebab mereka sedang dalam masa pertumbuhan sehingga rentan terhadap polutan di udara. Oleh sebab itu $\mathrm{CO}_{2}$ sering dijadikan sebagai indikator kecukupan ventilasi untuk mengakomodasi kebutuhan udara segar (oxygen) dan mempertahankan kualitas udara di dalam ruang kelas dengan catatan keberadaan pencemar udara lain dianggap tidak berbahaya.

Konsentrasi $\mathrm{CO}_{2}$ di dalam ruang kelas akan bertambah tergantung beberapa faktor antara lain jumlah dan aktivitas siswa, densitas atau tingkat kepadatan penghunian ruang, lama berada di dalam ruang serta jumlah udara segar yang masuk ke dalam ruang (ventilation rates). Mengurangi konsentrasi $\mathrm{CO}_{2}$ di dalam ruang kelas hanya dapat dilakukan dengan cara pengenceran yaitu melalui pertukaran udara atau memasukkan udara segar ke dalam ruang dengan memanfaatkan ventilasi yaitu ventilasi alami [13], ventilasi mekanis [10], atau menggabungkan keduanya [8].

Menggunakan ventilasi alami untuk menciptakan kualitas udara yang sehat di dalam ruang kelas lebih menguntungkan karena hemat energi. Di daerah beriklim panas lembab bukaan berupa jendela atau ventilasi alami yang terbuka luas berperan penting menciptakan kenyamanan termal dan kualitas udara di dalam ruang. Razali et al. (2015) menemukan konsentrasi $\mathrm{CO}_{2}$ di beberapa ruang kelas sekolah yang menggunakan ventilasi alami di Malaysia, < 700 ppm atau di bawah standar yang direkomendasikan oleh ASHRAE yaitu 1000 ppm. Konsentrasi $\mathrm{CO}_{2}$ di ruang kelas yang menggunakan ventilasi alami dipengaruhi oleh ukuran, jumlah, dan posisi bukaan atau jendela [4] (Mumovic, Davies, Ridley, Altamirano-Medina, \& Oreszczyn, 2009). von Grabe, Svoboda, and Bäumler (2014) menemukan ventilasi dengan jendela tipe gantung atas memiliki performa paling buruk dalam hal mengencerkan konsentrasi $\mathrm{CO}_{2}$ di dalam ruang.

Umumnya ruang kelas sekolah dasar negeri di kota Medan menggunakan jendela dan/atau ventilasi alami untuk penerangan dan memasukkan udara ke dalam ruang yang dibutuhkan untuk kenyamanan termal dan kualitas udara. Tipe, luas, dan letak/lokasi jendela yang digunakan beragam walaupun ada kebijakan terkait bukaan di ruang kelas untuk menjamin terpenuhinya penerangan di dalam ruang. Salah satu tipe jendela yang digunakan adalah tipe gantung atas dengan jalusi horisontal di atasnya. Studi bermaksud menyelidiki performa jendela tersebut dalam mengencerkan konsentrasi $\mathrm{CO}_{2}$ di dalam ruang kelas.

\section{Metode Penelitian}

Penelitian dilakukan dengan metoda eksperimental, monitoring konsentrasi $\mathrm{CO}_{2}$ pada ruang kelas yang dijadikan sebagai obyek studi dengan menggunakan $\mathrm{CO}_{2}$ data logger Trotec BZ 30 dengan spesifikasi kemampuan mengukur $\mathrm{CO}_{2}$ 0-50.000 ppm setiap 2 detik selama 20 jam sekaligus mengukur suhu dan kelembaban udara. Monitoring dilakukan selama tiga hari sebelum waktu belajar hingga selesai (pukul 7.06 - $12.30 \mathrm{WIB}$ ). Beberapa pertimbangan yang digunakan untuk menentukan ruang kelas antara lain adalah jumlah siswa, ukuran kelas, serta luas dan letak bukaan.

\subsection{Jumlah Siswa dan Densitas Ruang}

Untuk mempertahankan kualitas udara di dalam ruang, ASHRAE [3] merekomendasikan kepadatan maksimum di dalam ruang kelas adalah 50 orang/100 $\mathrm{m}^{2}$ atau $2 \mathrm{~m}^{2}$ orang sama halnya dengan Peraturan Menteri Pendidikan Nasional (Permendiknas) No. 24 tahun 2007 tentang Standar Sarana dan Prasarana Sekolah, dengan jumlah siswa untuk satu rombongan belajar di tingkat sekolah dasar maksimal 28 orang. Berbeda dengan ketentuan tersebut, Permendiknas No. 15 tahun 2010 tentang Standar Pelayanan Minimal Pendidikan Dasar di Kabupaten/Kota menetapkan jumlah siswa maksimal setiap rombongan belajar siswa sekolah dasar adalah 32 orang tanpa menentukan densitas ruang. Untuk menjamin kesehatan di lingkungan sekolah, Keputusan Menteri Kesehatan No. 1429 /MENKES/SK/2006 tentang Pedoman Penyelenggaraan Kesehatan Lingkungan Sekolah menetapkan densitas ruang kelas $1,75 \mathrm{~m}^{2} /$ orang. Ukuran ruang kelas untuk sekolah dasar ditetapkan $7 \mathrm{~m} \mathrm{x} 8 \mathrm{~m}$ atau luas $56 \mathrm{~m}^{2}$ (Dasar, 2015; Kebudayaan, 2011, 2013; Nasional, 2012). 


\subsection{Kebijakan terkait Ventilasi dan Kualitas Udara di Ruang Kelas Sekolah Dasar}

Bukaan untuk ruang kelas sekolah dasar dimaksudkan untuk mengakomodasi kebutuhan pencahayaan alami dan ventilasi (Nasional, 2009). Bukaan untuk pencahayaan terbuat dari kaca mati dengan ambang bawah jendela minimal $1,10 \mathrm{~m}$ dari atas lantai sedangkan bukaan untuk ventilasi menggunakan prinsip ventilasi silang menggunakan jalusi kayu, kaca silang, kaca tidak penuh atau daun ventilasi dari kaca. SNI 03-6572-2001 tentang Tata cara perancangan sistem ventilasi dan pengkondisian udara pada bangunan gedung (tidak spesifik untuk ruang kelas) menentukan untuk bangunan yang menggunakan ventilasi alami maka ventilasi yang disediakan harus terdiri dari bukaan permanen, jendela, pintu atau sarana lain yang dapat dibuka dan jumlah bukaan ventilasi permanen minimal 5\% terhadap luas lantai ruangan. Luas lubang ventilasi untuk menjamin aliran udara segar dalam ruang kelas di lingkungan sekolah mengacu pada Keputusan Menteri Kesehatan No. 1429 /MENKES/SK/2006 tentang Pedoman Penyelenggaraan Kesehatan Lingkungan Sekolah adalah 20\% dari luas lantai dengan kepadatan kelas minimal $1,75 \mathrm{~m}^{2}$ dan tinggi langit-langit minimal $3 \mathrm{~m}$ dari permukaan lantai. Lampiran II Permendikbud No. 32 tahun 2011 tentang Standar dan Spesifikasi Teknis Rehabilitasi Ruang Kelas Rusak, P embangunan Ruang Kelas Baru beserta Perabotnya dan Pembangunan Ruang Perpustakaan Beserta Perabotnya untuk SD/SDLB menetapkan luas bukaan 20\% dari luas total lantai bangunan dan lebih rinci menetapkan 6\% - 10\% dari luas tersebut berupa ventilasi (bukaan permanen) dengan prinsip ventilasi silang atau ventilasi satu sisi.

\subsection{Perletakan Alat Ukur $\mathrm{CO}_{2}$}

Studi sebelumnya [14] menunjukkan bahwa kadar $\mathrm{CO}_{2}$ di dalam ruang kelas tidak terdistribusi merata dan untuk pengukuran pada ruang dengan luas hingga $100 \mathrm{~m}^{2}$ cukup dilakukan pada satu titik di tengah ruangan pada zona ketinggian bernafas siswa dalam kondisi duduk [15].

\section{Hasil dan Diskusi}

Dengan pertimbangan jumlah siswa, densitas ruang, lama siswa di dalam ruang kelas, luas bukaan, dan tipe jendela yang digunakan maka obyek studi adalah ruang kelas V SDN 066046 di Kecamatan Helvetia.

\subsection{SDN 066049}

SDN 066046 berada di Jl. Tanjung Perumnas Helvetia, Kecamatan Helvetia Medan, berdampingan dengan SDN 066049. Perletakan massa seluruh bangunan membentuk massa dengan pola courtyard tertutup (Gambar 3.1). Jumlah siswa SDN 066046 seluruhnya 302 orang terbagi dalam 10 rombongan belajar. Waktu belajar siswa adalah pukul 07.30 - 12.05 yang diselingi 2 x jam istirahat masing-masing 15 menit (pukul 09.15- 09.30 dan pukul 10.40 - 10.55 ) untuk hari Senin s/d Kamis, pukul 07.30 - 10.40 pada hari Jumat dan pukul 07.30 - 10.00 pada hari Sabtu masing-masing diselingi $1 \mathrm{x}$ jam istirahat selama 15 menit. SDN 066046 memiliki 9 ruang kelas berukuran 7,4 $\mathrm{m}$ x 7,0 $\mathrm{m}\left(51.8 \mathrm{~m}^{2}\right)$, tinggi lantai-plafon 3,25 $\mathrm{m}$ dan total luas bukaan $16,46 \mathrm{~m}^{2}$ atau $32 \%$ dari luas lantai ruang kelas.
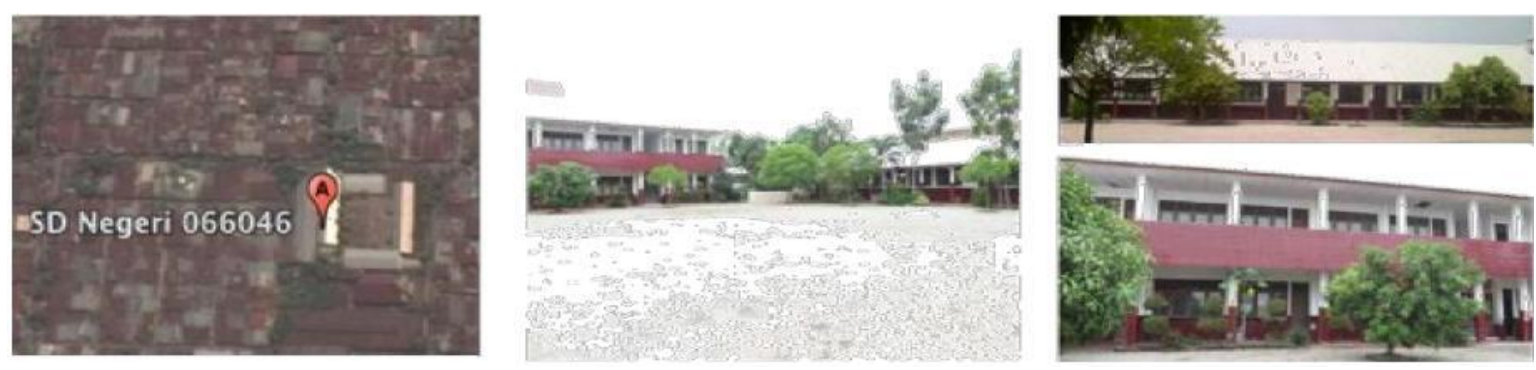

Gambar 1. Lokasi, Bentuk Massa Bangunan dan Suasana sekolah SDN 066046 dan SDN 066049 
Penelitian dilakukan di ruang kelas V SDN 066046 sebagaimana dapat dilihat pada Gambar 2, dengan jumlah siswa 30 orang.
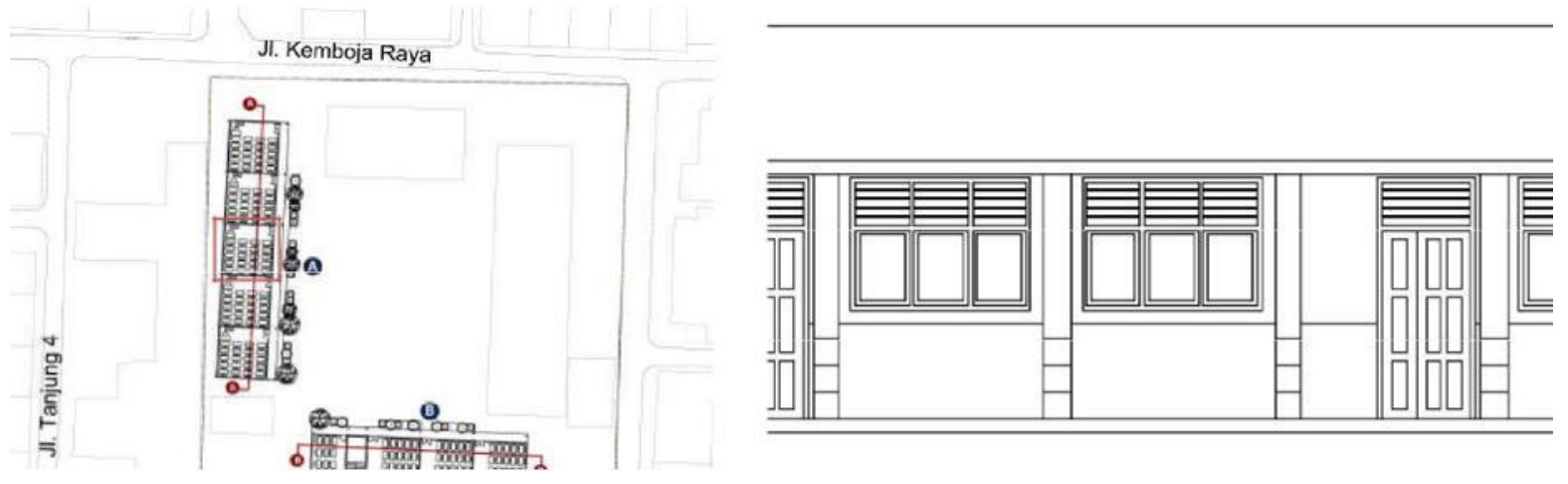

Gambar 2. Tampak Depan R. Kelas V
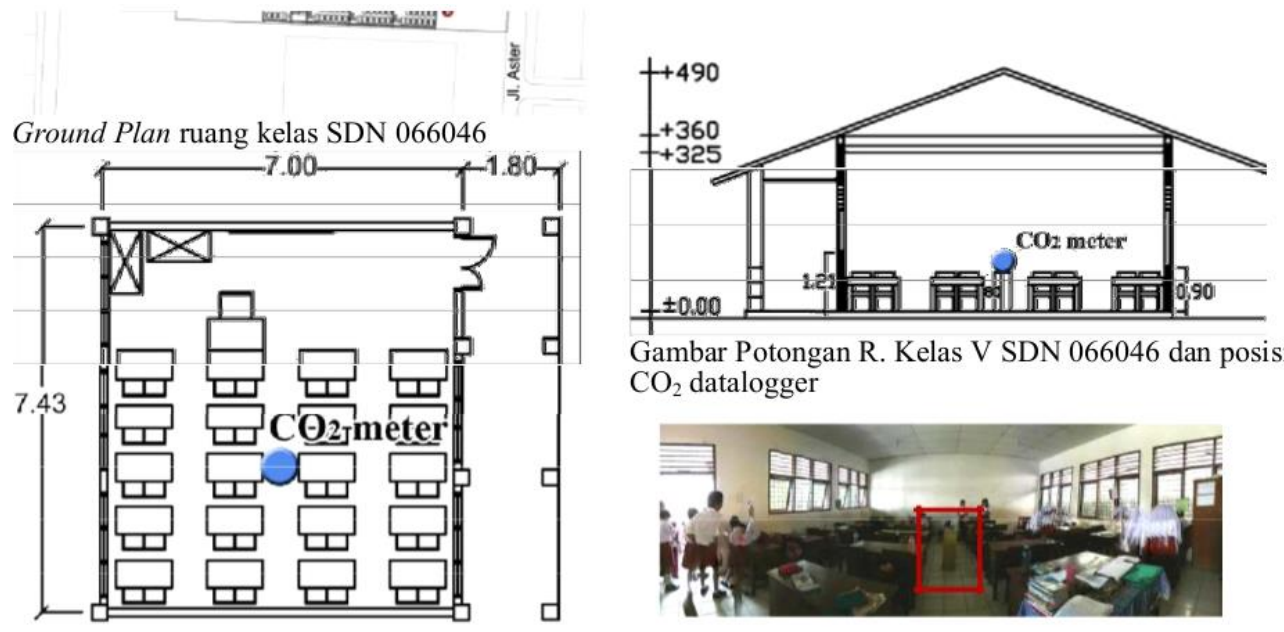

Gambar Potongan R. Kelas V SDN 066046 dan posisi $\mathrm{CO}_{2}$ datalogger

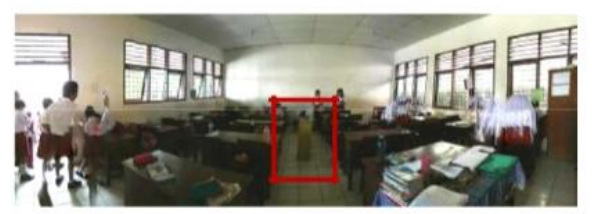

Gambar Denah R. Kelas V dan posisi $\mathrm{CO}_{2}$ Suasana R. Kelas V SDN 066046 datalogger

Gambar 3: Denah, Tampak, Potongan dan Suasana ruang kelas obyek studi (Kelas V)

Ruang kelas menggunakan bukaan tipe jendela gantung atas dengan ventilasi permanen berupa jalusi horisontal di atasnya. Ukuran lubang ventilasi permanen @ 0,6 m x 0,58 m, sehingga luas total 5, $22 \mathrm{~m} 2$ atau 10\% dari luas lantai ruang kelas. Ambang bawah jendela pada sisi koridor berada pada ketinggian 1,20 m di atas lantai sementara pada sisi yang berlawanan berada pada ketinggian $90 \mathrm{~cm}$ di atas lantai. Jendela pada sisi koridor terdiri dari 2 unit, masing-masing dengan ukuran $200 \mathrm{~cm} \times 146 \mathrm{~cm}$, terdiri dari 3 lubang dengan perincian 2 lubang jendela tipe gantung atas (ukuran @ 0,9 m x 1,2 m) dan 1 lubang jendela di bagian tengah tipe jendela mati (fix light) dengan ukuran yang sama. Pada sisi yang berlawanan, jendela terdiri dari 3 unit masing-masing dengan ukuran $200 \mathrm{~cm} \mathrm{x}$ $177 \mathrm{~cm}$ dengan tipe yang sama sebagaimana dapat dilihat pada Gambar 3. 

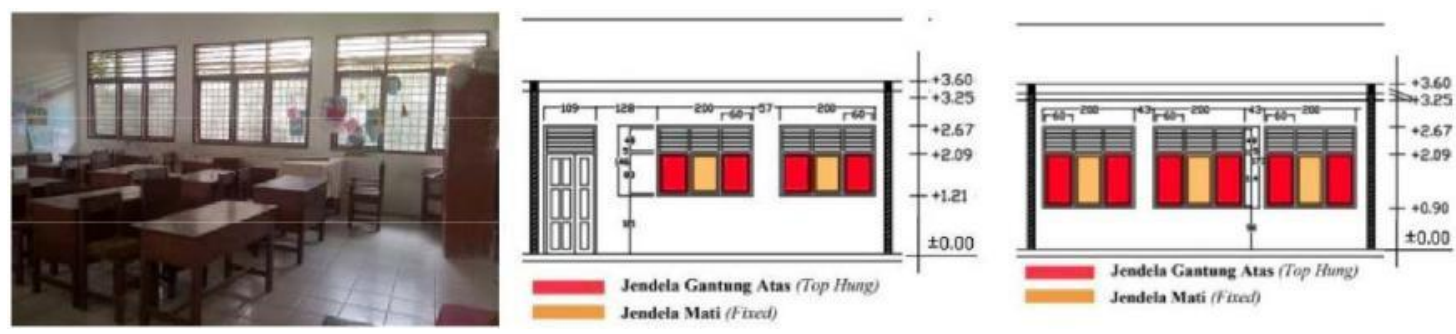

Gambar 4 : Tipe jendela ruang kelas obyek studi

\section{Monitoring $\mathrm{CO}_{2}$}

Monitoring terhadap konsentrasi $\mathrm{CO}_{2}$ di dalam ruang kelas dilakukan pada kondisi posisi sudut inklinasi jendela sisi koridor dibuka $10^{\circ}$ dan $30^{\circ}$ masing-masing selama tiga (3) hari. Karena alasan teknis jendela sisi yang berlawanan dalam kondisi tertutup namun pintu tetap terbuka selama waktu pengukuran.

Konsentrasi $\mathrm{CO}_{2}$ pada Posisi Sudut Inklinasi Jendela $10^{\circ}$

Monitoring dilakukan tanggal 20 April 2016 (Hari 1), 21 April 2016 (Hari 2), dan 25 April 2016 (Hari 3). Pada Gambar 1, grafik memperlihatkan secara umum konsentrasi $\mathrm{CO} 2$ berada di bawah standar yang diijinkan untuk kesehatan $(<1000 \mathrm{ppm})$.

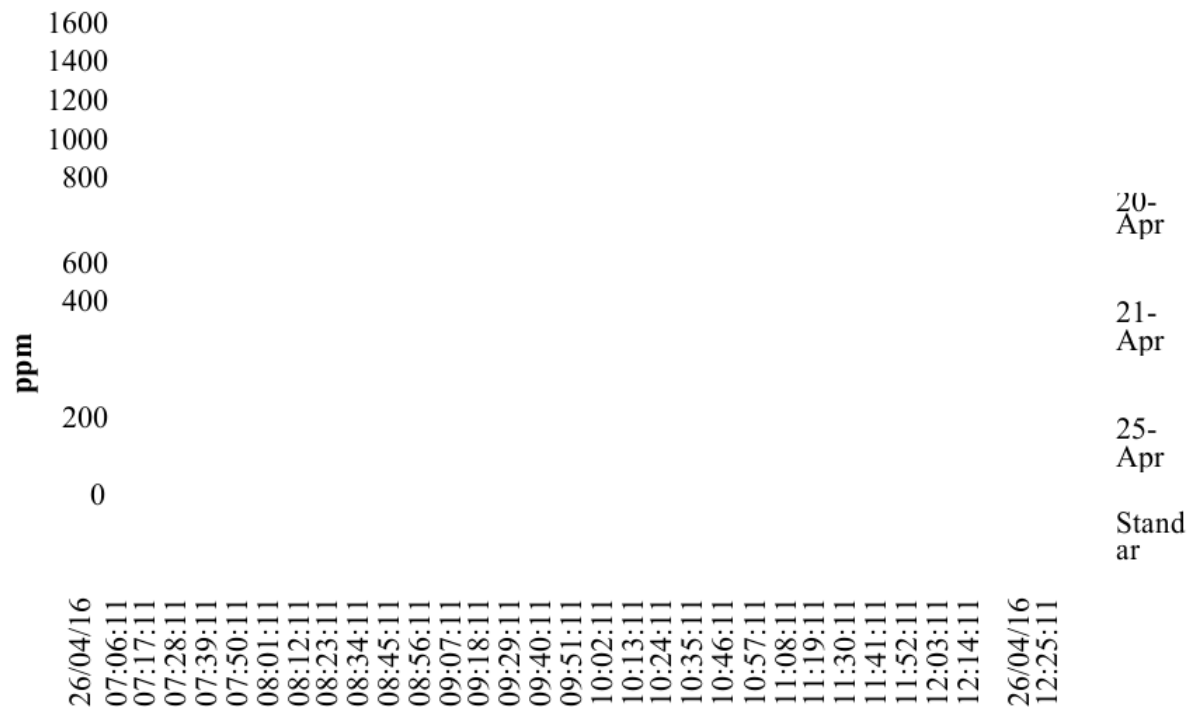

Gambar 4: Grafik konsentrasi $\mathrm{CO} 2$ pada posisi sudut inklinasi jendela $10^{\circ}$

Hasil pengukuran menunjukkan konsentrasi $\mathrm{CO}_{2}$ minimum selama 3 hari pengukuran berada pada rentang 397 ppm - 430 ppm yang terjadi pada saat waktu belajar usai, konsentrasi maksimum pada rentang 871ppm - 1447 ppm. Konsentrasi $\mathrm{CO}_{2}$ rata-rata berada pada rentang 596,5 ppm - 644,5 ppm masih berada dibawah ambang batas yang diijinkan untuk kesehatan mengacu pada ASHRAE (Tabel 1).

Tabel 1: Konsentrasi CO2 Rata-rata, Median, Maksimum dan Minimum pada posisi sudut inklinasi jendela $10^{0}$

\begin{tabular}{llll}
\hline & \multicolumn{4}{l}{ Konsentrasi $\mathrm{CO} 2(\mathrm{ppm})$} & Hari 3 \\
\cline { 2 - 4 } Hari 1 & Hari 2 & 596.5 \\
Rata-rata & 644.5 & 635.3 & 596.0 \\
Median & 622.0 & 632.0 & \\
\hline
\end{tabular}




\begin{tabular}{llll}
\hline Maksimum & 1.395 .0 & 1.447 .0 & 871.0 \\
Minimum & 416.0 & 430.0 & 397.0 \\
\hline
\end{tabular}

Pengukuran pada Posisi Sudut Inklinasi Jendela $30^{\circ}$

Monitoring konsentrasi CO2 dilakukan berturut-turut selama tiga hari yaitu pada tanggal 9 Mei 2016 (Hari 4), 10 Mei 2016 (Hari 5), dan 11 Mei 2016 (Hari 6). Pada Gambar 5 dapat dilihat grafik pengukuran selama tiga hari yang menunjukkan konsentrasi CO2 pada umumnya berada di bawah ambang batas yang diijinkan untuk kesehatan $(<$ 1000 ppm). Monitoring menunjukkan konsentrasi CO2 sesaat yang sangat tinggi pada tanggal 11 Mei (6.455 ppm) yang terjadi pada pukul 11.55, kemungkinan terjadi akibat siswa mendekati alat monitoring.

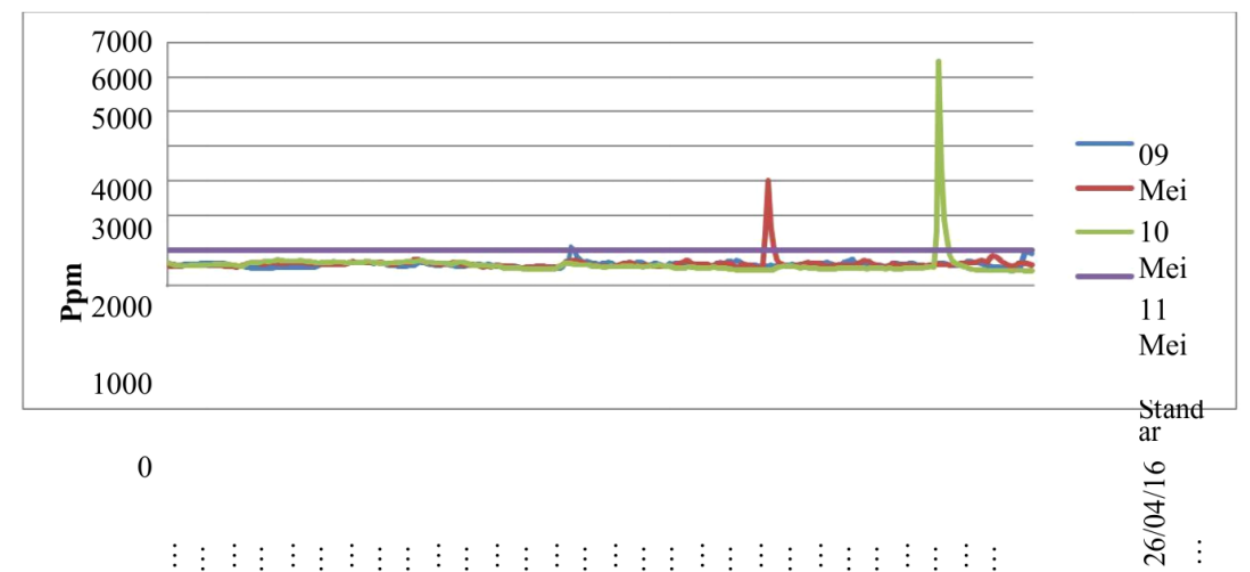

Gambar 5. Grafik konsentrasi $\mathrm{CO} 2$ pada posisi sudut inklinasi jendela $30^{\circ}$

Hasil pengukuran menunjukkan konsentrasi CO2 minimum berada pada rentang 405 ppm - 486 ppm selama 3 hari pengukuran. Konsentrasi CO2 maksimal berada pada rentang yang cukup jauh yaitu $1.090 \mathrm{ppm}-6.455 \mathrm{ppm}$. Rata-rata konsentrasi CO2 pada rentang 579 ppm - 605 ppm masih berada pada ambang batas yang dijinkan untuk kesehatan (Tabel 2).

Tabel 2. Konsentrasi CO2 Rata-rata, Median, Maksimum dan Minimum pada posisi sudut inklinasi

\begin{tabular}{llll}
\hline & \multicolumn{3}{l}{ Konsentrasi $\mathrm{CO} 2(\mathrm{ppm})$} \\
\cline { 2 - 4 } & Hari 4 & Hari 5 & Hari 6 \\
\hline Rata-rata & 581.8 & 605.0 & 579.0 \\
Median & 575.0 & 585.0 & 533.0 \\
Maksimum & 1.090 .0 & 3.004 .0 & 6.455 .0 \\
Minimum & 432.0 & 486.0 & 405.0 \\
\hline
\end{tabular}

Jika dibandingkan sebagaimana dapat dilihat pada Tabel 3, konsentrasi $\mathrm{CO}_{2}$ rata-rata pada kedua posisi sudut jendela berada di bawah ambang batas yang diijinkan untuk kesehatan $(<1000 \mathrm{ppm})$. Konsentrasi $\mathrm{CO}_{2}$ maksimum pada posisi sudut inklinasi jendela $30^{\circ}>1000 \mathrm{ppm}$ sementara pada posisi sudut inklinasi jendela $10^{\circ}$ masih ditemukan nilai maksimum konsentrasi $\mathrm{CO}_{2}<1000$ ppm.

Tabel 3: Pembandingan konsentrasi CO2 Rata-rata, Median, Maksimum dan Minimum pada posisi sudut inklinasi jendela $10^{\circ}$ dan $30^{\circ}$

\begin{tabular}{lllll}
\hline & \multicolumn{3}{l}{ Konsentrasi CO2 $(\mathrm{ppm})$} & \\
\cline { 2 - 5 } & \multicolumn{3}{l}{ Sudut $10^{\circ}$} & \multicolumn{3}{l}{ Sudut $30^{\circ}$} & \\
\hline Rata-rata & 596.5 & -644.5 & 579.0 & -605.0 \\
Median & 596.0 & -632.0 & 533.0 & -585.0 \\
Maksimum & $871.0-1.447 .0$ & $1.090 .0-6.455 .0$ \\
\hline
\end{tabular}




\begin{tabular}{llll}
\hline Minimum & 397 & -430.0 & $405.0-486.0$ \\
\hline
\end{tabular}

\section{Kesimpulan}

Studi menunjukkan bahwa penggunaan tipe jendela gantung atas dengan ventilasi permanen (jalusi horisontal) di atasnya yang ditempatkan pada posisi yang berlawanan (cross ventilation) dan luas $>20 \%$ dari luas lantai berfungsi baik mempertahankan kualitas udara di dalam ruang (konsentrasi $\mathrm{CO}_{2}$ sebagai indikator).

\section{Referensi}

[1] Alshitawi, M. S., \& Awbi, H. B. (2011). Measurement and prediction of the effect of students “ activities on airborne particulate concentration in a classroom. HVAC\&R Research, 17, 446-464. doi: 10.1080/10789669.2011.583708

[2] Aris, M. S. B. M. (2013). An Assessment of Indoor Air Quality at Two Contrasting Location and Building Ventilation Types in London. (Doctor of Philosophy Thesis), King's College London, London.

[3] ASHRAE. (1999). ASHRAE Standard 62-1999, Ventilation for Acceptable Indoor Air Quality (supersedes ANSI/ASHRAE 62-1989) Includes ASHRAE Addenda Listed in Appendix I.

[4] Beisteiner, A., \& Coley, D. A. (2003). Carbon Dioxide Levels and Summertime Ventilation Rates in UK Schools. International Journal of Ventilation, 1(3), 181-187. doi: 10.5555/ijov.2003.1.3.181

[5] Cai, G.-H., Hashim, J. H., Hashim, Z., Ali, F., Bloom, E., Larsson, L., . . Norbäck, D. (2011). Fungal DNA, allergens, mycotoxins and associations with asthmatic symptoms among pupils in schools from Johor Bahru, Malaysia. Pediatric Allergy And Immunology: Official Publication Of The European Society Of Pediatric Allergy And Immunology, 22(3), 290-297. doi: 10.1111/j.1399-3038.2010.01127.x

[6] Peraturan Direktur Jenderal Penddikan Dasar No. 144/C/KP/2015 tentang Petunjuk Pelaksanaan DAK Bidang Pendidikan Dasar Tahun Anggaran 2015 (2015).

[7] Freitas, M. d. C., Canha, N., Martinho, M., Almeida-Silva, M., Almeida, S. M., Pegas, P., .Contreiras, T. (2011). Indoor Air Quality in Primary Schools. In A. Moldoveanu (Ed.), Advanced Topics in Environmental Health and Air Pollution Case Studies (pp. 470): InTech. (Reprinted from: August, 2011). Retrieved from http://www.intechopen.com/books/export/citation/EndNote/advanced-topics-inenvironmental-health-and-air-pollution-case-studies/indoor-air-quality-in-primary-schools. doi: 18598

[8] Gao, J., Wargocki, P., \& Wang, Y. (2014). Ventilation system type, classroom environmental quality and pupils' perceptions and symptoms. Building and environment, 75(0), 46-57. doi: http://dx.doi.org/10.1016/j.buildenv.2014.01.015

[9] Greene, R., M.Eftekhari, D.Clements-Croome, \& G.Georgiou. (2012). Measurements of CO2 levels in a classroom and its effect on the performance of the students. Paper presented at the CIBSE ASHRAE Technical Symposium, Imperial College, London UK

[10] Kalema, T., \& Viot, M. (2014). Methods to Reduce the CO2 Concentration of Educational Buildings Utilizing internal Ventilation by Transferred Air. Indoor Air, 24, 71-80. doi: 10.1111/ina.12059

[11] Lampiran II Permendikbud No. 32 Tahun 2011 tentang Standar dan Spesifikasi Teknis Rehabilitasi Ruang Kelas Rusak, Pembangunan Ruang Kelas Baru Beserta Perabotnya dan Pembangunan Ruang Perpustakaan Beserta Perabotnya untuk SD/SDLB (2011).

[12] Peraturan Direktur Jenderal Penddikan Dasar No. 17809/A/LL/2013 tentang Petunjuk Pelaksanaan DAK Bidang Pendidikan Dasar Tahun Anggaran 2013 (2013).

[13] Khatami, N., Cook, M. J., Firth, S. K., \& Hudleston, N. (2013). Control of Carbon Dioxide Concentration in Educational Spaces Using Natural Ventilation. International Journal of Ventilation, 11(4), 339-352. doi: 10.5555/2044-4044-11.4.339

[14] Mahyuddin, N., \& Awbi, H. (2010). The spatial distribution of carbon dioxide in an environmental test chamber. Building and Environment, 45, 1993-2001.

[15] Mahyuddin, N., \& Awbi, H. B. (2012). A Review of CO2 Measurement Procedures in Ventilation Research. International Journal of Ventilation, 10(4), 353-370. doi: 10.5555/2044-404410.4.353

[16] Muscatiello, N., McCarthy, A., Kielb, C., Hsu, W. H., Hwang, S. A., \& Lin, S. (2014). Classroom conditions and CO2 concentrations and teacher health symptom reporting in 10 New York State Schools. Indoor Air, 25(2), 157-167. doi: 10.1111/ina.12136

[17] Lampiran IV Peraturan Menteri Pendidikan Nasional Nomor 3 Tahun 2009 Tanggal 29 Januari 2009 Standar/Spesifikasi Teknis Pembangunan/Rehabilitai Gedung dan Meubelair Sekolah Dasar (2009).

[18] Lampiran II Permendikbud No. 61 Tahun 2012 tentang Perubahan atas Permendikbud No 56 Tahun 2011 tentang Petunjuk Teknis Penggunaan DAK Bidang Pendidikan Tahun Anggaran 2012 untuk Sekolah Dasar/Sekolah Dasar Luar Biasa (2012).

[19] Raatikainen, M., Skön, J.-P., Turunen, M., Leiviskä, K., \& Kolehmainen, M. (2013).

Evaluating Effects of Indoor Air Quality in School Buildings and Students' Health:A Study in Ten Schools of Kuopio, Finland. Paper presented at the 2013 2nd International Conference on Environment, Energy and Biotechnology Singapore.

[20] Razali, N. Y. Y., Latif, M. T., Dominick, D., Mohamad, N., Sulaiman, F. R., \& Srithawirat, T. (2015). Concentration of particulate matter, $\mathrm{CO}$ and $\mathrm{CO} 2$ in selected schools in Malaysia. Building and environment, 87, 108-116.

[21] Ribéron, J., O‘Kelly, P., Maupetit, F., \& Robine, E. (2002). Indoor air quality in schools: the impact of ventilation conditions and indoor activities. Paper presented at the Indoor Air. 
[22] Rovelli, S., Cattaneo, A., Nuzzi, C. P., Spinazzè, A., Piazza, S., Carrer, P., \& Cavallo, D. M. (2014). Airborne Particulate Matter in School Classrooms of Northern Italy.

International Journal of Environmental Research and Public Health, 11(2), 1398-1421.

[23] Simpson, K. (2011). The indoor air quality of a Victorian school with a post-1968 extension. Paper presented at the Conference : People and Buildings, Network for Comfort and Energy Use in Buildings, London. 